\title{
Effect of Windbreaks and some Design Factors on Performance of Sprinkler Irrigation System
}

Awwad, A. H. and A. S. H. Mohammed

Res. Agric. Eng. Res. Inst. A. R. C. Egypt.

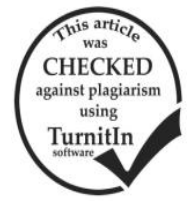

\section{ABSTRACT}

A field experiment was carried out during the successive growth season of 2015/2016 in order to study the effect of windbreaks and some factors of design on the performance of sprinkler irrigation system under open field conditions in sandy soil at Arab El- Awammer Research, Station, Agriculture Research Center- Assiut Governorate, Egypt. The objective of this work is to study the effect of presence or absence the windbreaks, height of rotating sprinkler, climatic conditions (temperature, wind speed and relative humidity) and layout of sprinkler irrigation on the spray evaporation loss, the actual water application, coefficient of uniformity (CU), distribution uniformity (DU), production yield and water use efficiency for sprinkler irrigation systems. The results indicated that; The lowest value of Spray evaporation loss (SEL) was $2.9 \%$ in Sep with height of rotating sprinkler $(50 \mathrm{~cm})$ and the highest value of SEL was $9.6 \%$ in August with height of rotating sprinkler $(70 \mathrm{~cm})$ with the presence of windbreaks. While with the absence of windbreaks, the lowest value of SEL was $10 \%$ in Sep with height of rotating sprinkler $(50 \mathrm{~cm})$ and the highest value of SEL was $28.7 \%$ in August with height of rotating sprinkler $(70 \mathrm{~cm})$. The wind speed increased by an average ratio $38 \%$, the air temperature increased by an average ratio $15 \%$ and relative humidity decreased by an average ratio $40 \%$ at the windbreaks were completely absent. The highest coefficient uniformity and distribution uniformity were obtained in June, while the lowest coefficient uniformity and distribution uniformity were obtained in August during the presence of windbreaks. The presence of windbreaks increased the productivity of the crop more than the absence of windbreaks, with the same height of rotating sprinkler and the same layout, the maximum Pods yield and the highest percentage of water use efficiency by interaction between presence of windbreaks and the low height of rotating sprinkler $(50 \mathrm{~cm})$. While, the lowest Pods yield and water use efficiency were produced due to interaction between the absence of windbreaks and the increasing height of rotating sprinkler to $70 \mathrm{~cm}$.

\section{INTRODUCTION}

Uddin et al., 2010 showed that sprinkler irrigation losses may change from 0 to $45 \%$ of the water application and that a large amounts of the loss is droplet evaporation in the atmosphere. So, sprinkler irrigation efficiency is affected by the amount of spray evaporation losses. Zazueta, 2011, reported that the amount of water which evaporates from water droplets is related to the evaporative demand of the atmosphere, which is affected by climatic conditions. The energy available for evaporation and the capacity of the air to store and transmit water vapour is called "evaporative demand". The evaporation process requires $2.42 \mathrm{~kJ}$ of energy to convert $1 \mathrm{gm}$ of water from liquid to gas form. So, sufficient energy has to be available from the environment around the sprinkler for evaporation to occur during irrigation. The climatic variables affecting wind drift and evaporation losses are wind speed, air temperature, relative humidity. An example of climatic variables is wind speed, which is one of the most important factors (Playán et al., 2005). Smajstrla \& Zazueta, 2003 showed that Wind speed leads to evaporation from the surrounding areas by moving warmer or drier air to displace the moist, cool air above an irrigated surface. It also raises the evaporation rates by moving water vapour from the irrigated surface. S, there was an increasing in the renewal of air around the drops with unsaturated air. Air temperature provides energy required for evaporation. As a data, during high levels of air temperature, energy is easily available. Conversely, low levels of air temperatures provide less energy for evaporation. Relative humidity ranged by $0 \%$ (low values indicating dry air) to $100 \%$ (high values indicating moist air). Since dry air has a greater capacity for moisture, evaporation will occur more easily when the air is dry than when it is moist. Field studies by Bavi et al., 2009 showed that spray evaporation losses ranging from $0 \%$ to $45 \%$. Kincaid \& Longley, 1989 said that in some of the field studies, researchers have combined losses due to spray evaporation and spray drift together, to "spray losses", due to difficulties with the measurement techniques necessary to separate the two. Rate of evapotranspiration for vegetation is a function of four critical factors: wind speed, vapour pressure, air temperature and solar radiation. Where, solar radiation and wind speed are the most important factors affecting evapotranspiration in the Canterbury region (de Vries et al., 2010). Windbreaks have used in many previous periods to defend against the damaging effects of wind and to modify wind profiles and therefore reduce soil erosion and increase crop yield (Guan et al., 2003). Decrease of wind speed by windbreaks is beneficial in irrigation systems where;

- Increasing the efficiency of sprinkler irrigation and the atmospheric evaporative demand in the protected area is also decrease. In turn, the Spray evaporation loss between the sprinkler and the surface is reduced, thus decreasing Spray evaporation loss. Hence, the amount of applied water used per unit of crop yield is reduced, which mean increasing water use efficiency;

-Decreasing evapotranspiration. Wind speed is an important factor that measured the evapotranspiration on the field. In windy areas, for example, Canterbury region, decreasing of wind speed by windbreaks lowers crop evapotranspiration and hence water requirements;

-If water requirements are reduced as a result of wind protection, energy costs related with the water applied like pumping are also reduced.

In United States, Dickey (1988) showed that in areas of high evapotranspiration $(10 \mathrm{~mm} /$ day $)$, a windbreak could improve irrigation application efficiency of fine spray by $10 \%$ by decreasing the wind speed from $4.5 \mathrm{~m} / \mathrm{s}$ to $1.8 \mathrm{~m} / \mathrm{s}$ and reported that any more reduction in wind speed would result in greater irrigation efficiencies, especially at high of evapotranspiration rates. In North America, shelter that reduced the wind speed especially in hot dry summer in a lucerne crop by $40 \%$ with a $10 \%$ saving of irrigation water. For dry land crops in the same trial, shelter was responsible for a $9 \%$ increase in crop yield, soil moisture being consistently higher beneath the 
sheltered crops. In New Zealand, studies have also shown that windbreaks can have great benefits in terms of saving water resource use in agriculture. de Vries et al. (2010) studied the effect of windbreaks on irrigation requirement and evapotranspiration in the field in the Canterbury region which was protected by a single windbreak using a modeling approach. Irrigation water requirements were estimated by calculating actual evapotranspiration for a pasture crop at different horizontal distances from a windbreak. Data showed that windbreak shading can decrease solar radiation by a ratio $90 \%$ on a full sunshine day and, if combined with reduction in wind speed, evapotranspiration can be decreased to $0 \%$ for dense windbreak. Data also showed that windbreaks can decrease on-farm water requirement by $10 \%$ to $20 \%$ and still maintain ideal farm yield. Data showed that for a typical field in Canterbury with a total length of $300 \mathrm{~m}$, the total reduction from just shade is $3 \%$ at mid-day and $9 \%$ in the afternoon. In general, when crops transpire water, the immediate around environment of the green parts of plant will be moist. In dry climates, the wind speed is most likely to replace this moist air with dry air, which causes an increase in evapotranspiration. Increase in evapotranspiration causes an increase in water requirements. Evapotranspiration is main source of water loss in agriculture. Among the key factors that affect wind speed, solar radiation and Evapotranspiration are the most important factors affecting evapotranspiration in the Canterbury region. So, wind speed can be controlled by use of windbreaks in a farm. Data showed that evapotranspiration of a crop can be determined by using the Standardized Reference Evapotranspiration Equation, if the meteorological variables are known Eric (2015). The aim of this work is to study the effect of presence or absence the windbreaks, height of rotating sprinkler, climatic conditions and layout of sprinkler irrigation on the spray evaporation loss, the actual water application, coefficient of uniformity (CU), distribution uniformity (DU), production yield and water use efficiency for sprinkler irrigation systems.

\section{MATERIALS AND METHODS}

Field experiment was carried out during the successive growth season of 2015/2016 at the experimental farm of Arab El- Awammer Research, Station, Agriculture Research Center, Assiut, Egypt. This work was done in four steps: (first) spray evaporation losses and the actual water application were measured under climatic variables;(second) measuring the distribution uniformity and coefficient uniformity;(third) studying the growth and yield of peanut plants grown and (fourth) measuring the water use efficiency under sprinkler irrigation systems to study the effect of presence or absence the windbreaks, height of rotating sprinkler, climatic variables and layout of sprinkler irrigation system on the performance of sprinkler irrigation system.

\section{Sprinkler irrigation experiment.}

The sprinkler irrigation system was fixed in square and triangular spacing pattern $(12 \mathrm{~m} \mathrm{X} 12 \mathrm{~m})$. The rotating sprinkler heights were 0.7 and $0.5 \mathrm{~m}$ above the ground with flow rate of $1.2-1.4 \mathrm{~m} 3 / \mathrm{h}$ at $2-3$ bars. The experiment included eight treatments under fixed sprinkler irrigation system which was showed in table 1 . The sprinklers line, which was taken measurements in the middle of the experiment land for all treatments, was about 48 meters from the windbreaks.

Table 1. Treatments of the experimental under fixed sprinkler irrigation system.

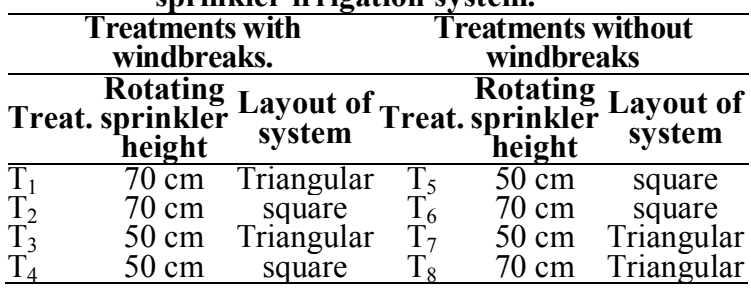

Peanut crop:-

Peanut seeds (Gize 5, variety) were mixed with peat treated with suitable species of rizobium just before planting process. The seeds were transplanted on the first day of June. Plants were harvested on 10th of October. All field practices for growing peanut were conducted as recommended. Eight different treatments were considered to evaluate fixed sprinkler irrigation system. The actual water applied (m3) for Peanut plants per season were $3785.03 \mathrm{~m} 3 / \mathrm{fed} / \mathrm{season}$. The sequence of calculation to estimate the gross irrigation water as shown in table 2.

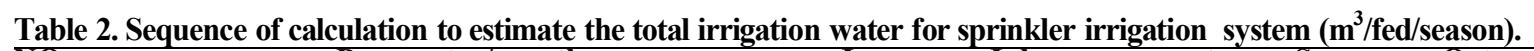

\begin{tabular}{|c|c|c|c|c|c|c|}
\hline NO. & Parameter/month & June & July & august & Sep. & Oct. \\
\hline 1 & ETo (mm/mont) & 210 & 248 & 263.5 & 180 & 146.01 \\
\hline 2 & ETo (mm/day) & 7.00 & 8.00 & 8.50 & 6.00 & 4.71 \\
\hline 3 & $\mathrm{~K}_{\mathrm{c}}$ & 0.4 & 0.6 & 1 & 1 & 0.85 \\
\hline 4 & $\mathrm{~K}_{\mathrm{r}}$ & 0.75 & 0.85 & 0.95 & 0.95 & 0.95 \\
\hline 5 & ETc (mm/day) & 2.10 & 4.08 & 8.08 & 5.70 & 3.81 \\
\hline 6 & Irrigation efficiency (Ea) & 0.8 & 0.8 & 0.8 & 0.8 & 0.8 \\
\hline 7 & $\operatorname{ETc}(\mathrm{mm} / \mathrm{day})$ & 2.63 & 5.10 & 10.09 & 7.13 & 4.76 \\
\hline 9 & Leaching requirement (LR) & 0.1 & 0.1 & 0.1 & 0.1 & 0.1 \\
\hline 10 & Gross daily (IR) ( $\mathrm{mm} /$ day) & 2.92 & 5.67 & 11.22 & 7.92 & 5.29 \\
\hline 11 & Days of water application & 30 & 31 & 31 & 30 & 10 \\
\hline 12 & Gross month (IR) (mm/month) & 87.50 & 175.67 & 347.67 & 237.50 & 52.86 \\
\hline 13 & Gross irri. (IR) (cm/ month) & 8.75 & 17.57 & 34.77 & 23.75 & 5.29 \\
\hline 14 & Total irri. (IR) (cm/fed/season) & & & 90.12 & & \\
\hline 15 & Total irri. (IR) (m/fed/season) & & & 3785.03 & & \\
\hline
\end{tabular}

\section{Specification of windbreaks:}

Casuarin were trees that have been cultivated as windbreaks, where the height of 5.5 meters and the distance between the trees 1.25 meters. The distance between the windbreaks line and the experiment land was 7 meters. Wind was westerly towards the east. Analysis of soil

The particle size distribution of soil samples was carried out according to the international pipette method (Klute, 1986). Soil bulk density was determined using 
undisturbed soil samples for the different layers of the soil profile using cylinder method (Klute, 1986). The capacity of available water (AWC) was calculated by the differences in water content at field capacity (FC) and permanent wilting point (PWP) as follows:

$$
\text { AWC }=\text { FC - PWP }
$$

Measurements and calculations of some soil chemical properties were made using the techniques described by (Jackson, 1973. Some soil physical and chemical properties were measured and recorded in table 3 and 4.

Table 3. Soil physical properties of the experimental field before cultivation.

\begin{tabular}{|c|c|c|c|c|c|c|c|c|c|c|c|c|}
\hline Soil depth & gravel & dis & $\begin{array}{l}\text { ticle } \\
\text { butio }\end{array}$ & $\begin{array}{l}z e \\
\%\end{array}$ & & O.M & $\mathrm{CaCO}_{3}$ & & $\begin{array}{l}\text { ture ce } \\
\text { umets }\end{array}$ & & & $\mathbf{P b}$ \\
\hline & $(\%$ & Sand & Silt & Clay & & & & S.P. & F.C. & W.P. & & \\
\hline $0-15$ & 34.5 & 90.9 & 6.7 & 2.4 & sandy & 0.3 & 32 & 25.2 & 12.5 & 4.9 & 7.6 & 1.57 \\
\hline $15-30$ & 30.2 & 90.2 & 6.8 & 3.0 & sandy & 0.28 & 33 & 23.3 & 10.0 & 4.2 & 5. & 1.65 \\
\hline $30-45$ & 46.6 & 89.4 & 7.4 & 3.2 & Sandy & 0.24 & 25.4 & 21.7 & 9.5 & 4.0 & 5.6 & 1.75 \\
\hline $45-60$ & 46.3 & 89.0 & 7.5 & 3.5 & Sandy & 0.16 & 32. & 23.0 & 11.8 & 4.9 & 6.9 & 1.55 \\
\hline mean & 39.4 & 89.9 & 7.1 & 3.0 & Sandy & 0.25 & 30.9 & 23.3 & 10.9 & 4.5 & 6.5 & 1.63 \\
\hline
\end{tabular}

O. M- Organic matter, S.P- Saturation percentage, F.C- Field capacity, W.P- Wilting point, A.W- Available water, Pb - Bulk density,

Table 4. Soil chemical properties of the experimental field before cultivation.

\begin{tabular}{|c|c|c|c|c|c|c|c|c|}
\hline \multirow[t]{2}{*}{ Soil depth,Cm } & \multirow{2}{*}{$(\mathbf{p H})$} & \multirow{2}{*}{$\begin{array}{c}\text { EC, Ds/m } \\
(1: 1)\end{array}$} & \multicolumn{4}{|c|}{ Soluble cations $\left(\mathrm{mmol} / \mathrm{L}^{-1}\right)$} & \multicolumn{2}{|c|}{$\begin{array}{l}\text { Soluble anions } \\
\left(\mathrm{mmol} / \mathbf{L}^{-1}\right)\end{array}$} \\
\hline & & & $\mathrm{Ca}^{12}$ & $\mathbf{M g}^{\prime 2}$ & $\mathbf{N a}$ & $\mathbf{K}$ & $\mathrm{Co}_{3} \mathrm{HCO}_{3}$ & $\mathrm{CT}^{-}$ \\
\hline $0-15$ & 8.10 & 0.42 & 2.16 & 1.40 & 0.29 & 0.96 & 2.25 & 2.00 \\
\hline $15-30$ & 8.50 & 0.39 & 1.46 & 1.52 & 0.19 & 0.95 & 1.90 & 1.80 \\
\hline $30-45$ & 8.55 & 0.26 & 1.08 & 0.89 & 0.14 & 0.61 & 1.42 & 1.17 \\
\hline $45-60$ & 8.34 & 0.24 & 1.01 & 0.82 & 0.13 & 0.47 & 1.15 & 0.89 \\
\hline mean & & 0.3 & 1.43 & 1.16 & 0.19 & 0.75 & 1.68 & 1.47 \\
\hline
\end{tabular}

Pan evaporation equation.

The class A evaporation pan is circular, $120.7 \mathrm{~cm}$ in diameter and $25 \mathrm{~cm}$ deep it is made of galvanized iron. The pan evaporation was sitting beside the experiment. Pan evaporation readings were taken daily in the early morning with using micrometer. Reference evapotranspiration values were calculated according to Pan Evaporation method (Doorenbos and Pruitt, 1977) using the following equation:

\section{Where:}

$$
\mathbf{E T}_{\mathbf{0}}=\mathbf{K}_{\text {pan }} \times \mathbf{E}_{\text {pan }}
$$

$\mathrm{ET}_{\mathrm{o}}$ : Reference evapotranspiration $\mathrm{mm} /$ day.

$\mathrm{K}_{\text {pan }}:$ Pan evaporation $\mathrm{mm} /$ day.

$\mathrm{E}_{\text {pan }}$ : pan coefficient $(0.7: 0.8)$.

Reference evapotranspiration $\left(\mathrm{ET}_{\mathrm{o}}\right)$

The reference $\mathrm{ET}_{\mathrm{o}}$ was estimated, using available meteorological data of Assiut governorate. Crop evapotranspiration (Etc). (Allen et al., 1998)

Where:

$$
E T_{c}=E T_{0} \times K c
$$

$\mathrm{Et}_{\mathrm{c}} \quad$ : Crop evapotranspiration.

$\mathrm{ET}_{\mathrm{o}}$ : Reference evapotranspiration with using FAO Penman- Monteith Equation.

$\mathrm{K}_{\mathrm{c}}$ :Crop coefficient, as reported by FAO (1979).
Actual irrigation water requirement

The amounts of actual applied irrigation water requirement under each irrigation treatment were determined according to James (1988) using the following equation:

$$
I \cdot R a=\frac{E T c+L f}{E r}
$$

Where:

I. $R_{a}$ : total actual irrigation water applied $\mathrm{mm} /$ interval.

$\mathrm{Et}_{\mathrm{c}}$ : Crop evapotranspiration using pan evaporation.

$\mathrm{L}_{\mathrm{f}} \quad$ : leaching factor $10 \%$.

$\mathrm{E}_{\mathrm{r}}$ : irrigation system efficiency.

Irrigation water use efficiency (IWUE)

The irrigation water use efficiency (IWUE) values were calculated as follows: (Vite, 1965)

$$
\text { IWUE }=\frac{\text { Grain or Seed yield }(\mathrm{KIg} / \mathrm{fed})}{\text { Irrigation water applied }\left(\mathrm{m}^{3} / \mathrm{fed} .\right)}
$$

\section{Application rate of sprinkler over the field}

The collection containers shall be put of equal size so that a grid of squares or rectangles is inside the selected sprayers as in figure (1), which indicates the layout of catch containers for testing the uniformity of sprinkler on lateral line in the field.

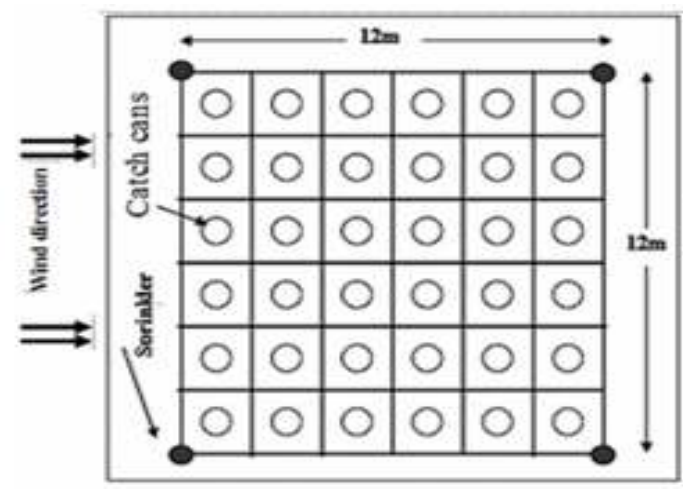

Square layout with absence of windbreaks

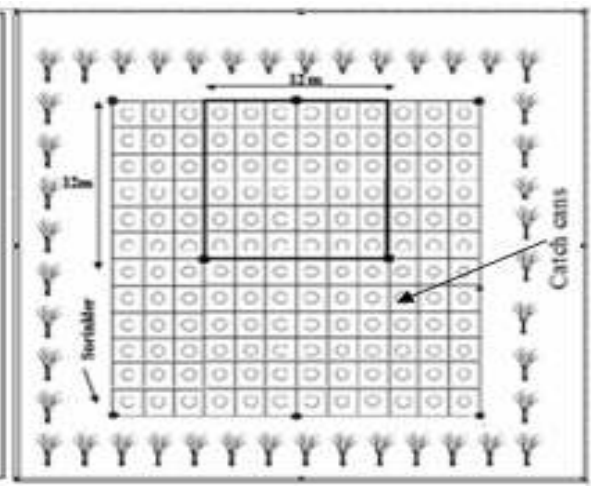

Triangular layout with presence of windbreaks

Figure 1. Layout of catch cans for testing the uniformity of distribution for sprinkler in the field. 
- Find the depth of water which collected in each cans by dividing the volume of water collected in each cans on the area of the cans section.

- Find the depth of water application $\left(D_{g}\right)$ using the following equation:-

\section{Where:}

$$
\mathbf{D}_{\mathrm{g}}=\mathbf{R}_{\mathrm{a}} \times \mathbf{T}_{\mathbf{i}}
$$

$\mathrm{T}_{\mathrm{i}}$ : operating time $(\mathrm{h})$

$\mathrm{R}_{\mathrm{a}}$ : application rate $(\mathrm{mm} / \mathrm{h})$

$R_{a}$ is found from the following equation:-

$$
\mathrm{R}_{\mathrm{a}}=\frac{\mathrm{Q}_{\mathrm{sp}}}{\mathrm{S}_{\mathrm{S}} \times \mathrm{S}_{\mathrm{L}}}
$$

$\mathrm{Q}_{\mathrm{sp}}$ actual application rate $(\mathrm{mm} / \mathrm{h})$.

Recording weather data at the time of system evaluation, especially wind speed and direction, relative humidity and average air temperature.

Coefficient of uniformity $(\mathrm{Cu})$

The sprinkler irrigation systems coefficient of uniformity was calculated from the following equation (Christiansen, 1942):-

$$
\mathrm{Cu}=\left(1-\frac{\sum_{\mathrm{i}=1}^{\mathrm{i}-\mathrm{n}}\left|\mathrm{X}_{\mathrm{i}}-\overline{\mathrm{X}}\right|}{\mathrm{n} \cdot \overline{\mathrm{X}}}\right) \times 100
$$

Where:

CU : Coefficient of uniformity, \%

$\mathrm{x}_{\mathrm{i}} \quad$ : Individual depth of catch observations from uniformity test, $\mathrm{mm}$

$\mathrm{x} \quad: \quad\left|\mathrm{x}_{\mathrm{i}}-\mathrm{x}\right|=$ absolute deviation of the individual observations from the mean, $\mathrm{mm}$.

$\mathrm{n}$ : Number of observed emitter or cans.

$\overline{\mathrm{X}}$ : Average depth of observations, mm.

Table 5. Data of climatic variables at the time of measurement with the absence and the presence of windbreaks.

\begin{tabular}{lcccccccc}
\hline & \multicolumn{4}{c}{ with windbreaks } & \multicolumn{3}{c}{ without windbreaks } \\
\hline Climatic variables & $\begin{array}{c}\text { Test 1 } \\
\text { (June) }\end{array}$ & $\begin{array}{c}\text { Test 2 } \\
\text { (July) }\end{array}$ & $\begin{array}{c}\text { Test 3 } \\
\text { (August) }\end{array}$ & $\begin{array}{c}\text { Test 4 } \\
\text { (Sept.) }\end{array}$ & $\begin{array}{c}\text { Test 5 } \\
\text { (June) }\end{array}$ & $\begin{array}{c}\text { Test 6 } \\
\text { (July) }\end{array}$ & $\begin{array}{c}\text { Test 7 } \\
\text { (Aug.) }\end{array}$ & $\begin{array}{c}\text { Test 8 } \\
\text { (Sept.) }\end{array}$ \\
\hline Air temperature (C $\left.{ }^{0}\right)$ & 30.71 & 29.4 & 33.76 & 24.8 & 36.4 & 34.1 & 38.4 & 30.8 \\
Wind velocity ( $\mathrm{km} \backslash \mathrm{h})$ & 9.8 & 2.51 & 4.1 & 13.09 & 15.7 & 4.4 & 7.2 & 18.7 \\
Relative humidity (\%) & 41.3 & 34.4 & 44 & 54.44 & 25.2 & 19 & 24 & 39 \\
\hline
\end{tabular}

Data also showed that the air temperature, in June, significantly increased from 30.71 Co under test 1 to 36.4 Co under test 5 , respectively, by $15.63 \%$. In the same trend, when the windbreaks are completely absence, the air temperature increased by $13.78 \%, 12.08 \%$, and $19.48 \%$ in July, August and sep. respectively.

Data also showed that the relative humidity, in June, significantly decreased from $41.3 \%$ under test 1 to $25.2 \%$ under test 5 , respectively, by $38.98 \%$. In the same trend, when the windbreaks are completely absence, the relative humidity decreased by $44.83 \%, 45.45 \%$, and $28.36 \%$ in July, August and sep. respectively.

Data also showed that the evaporation, in June, significantly increased from $6.3 \mathrm{~mm}$ under test 1 to 7.7 $\mathrm{mm}$ under test 5 , respectively, by $18.18 \%$. In the same trend, when the windbreaks are completely absence, the evaporation increased by $20 \%, 22.04 \%$, and $20 \%$ in July, August and sep. respectively. This means that windbreaks led to reduce evaporation across a field.

Data also showed that evaporation is a function of climatic variables, hence evapotranspiration is a function of

\section{Evaporation losses (E):}

The percentage of water lost by wind and air temperature can be found from the amount of water application in irrigation, during Operating time of equation:

$$
\mathrm{E}=\frac{\mathrm{D}_{\mathrm{g}}-\overline{\mathrm{X}}}{\mathrm{D}_{\mathrm{g}}} \times 100
$$

\section{Distribution of uniformity (DU)}

The distribution of uniformity indicates of application throughout the field and is computed by:-

$$
\mathbf{D U}=\frac{\text { Average low }- \text { quarter depth of water infiltrated }}{\text { Average depth of water infiltrated }}
$$

The average low quarter depth of water received is the average of the lowest one- quarter of the measured values, where each represents on equal area (Keller and Bliesner, 1990).

\section{RESULTS AND DISCUSSION}

\section{Climatic variables}

Average monthly meteorological data of Assiut weather station, which were measured (above $2 \mathrm{~m}$ on ground surface) during the growth season, are presented in table 5 and showed in figures (2, 3, 4 and 5).

Data showed that the wind speed, in June, significantly increased from $9.8 \mathrm{~km} / \mathrm{h}$ under test 1 to 15.7 $\mathrm{km} / \mathrm{h}$ under test 5 , respectively, by $37.58 \%$. In the same trend, when the windbreaks was absence, the wind speed increased by $42.95 \%, 43 \%$, and $30 \%$ in July, August and sep. respectively. This means that windbreaks led to reduce wind speeds across a field. climatic variables, and any change of wind speed and air temperature is expected to result in a change in evaporation and evapotranspiration. Comparison between all treatments showed that there was a significant difference between average evaporation. However, data indicated that the average evaporation is affected by wind speed and air temperature. This difference in evaporation for different treatments under different scenarios is attributed to the difference in wind speed and air temperature when windbreaks were either completely removed, evaporation increased proportionately to increase in wind speed and air temperature.

Generally, The increase in relative humidity and the decrease in wind velocity and air temperature at treatments (T1, T2, T3 and T4) were due to the presence of the windbreak and the decrease in relative humidity and the increase in wind velocity and air temperature at treatments (T5, T6, T7 and T8) was due to the absence of the windbreak. The effects of this decreased in relative humidity and the increased in wind speed and air 
temperature as a result of windbreak removal or reduction is quantified next in terms of water use by crops.

Spray evaporation loss

Data in table 6 showed that the spray evaporation losses (SEL) changed from one catch can to another inside the irrigated area. The results showed that the average SEL from individual catch cans inside the irrigated area is pointed in each test, together with the average climatic variables during the test. SEL values at treatments $\left(T_{1}, T_{2}\right.$, $\mathrm{T}_{3}$ and $\mathrm{T}_{4}$ ) with the presence of windbreaks ranged from $4.6 \%$ to $7.5 \%$ under test (1). While ranged from $6.3 \%$ to $8.9 \%$ under test (2), ranged from $7.4 \%$ to $9.6 \%$ under test (3) and ranged from $2.9 \%$ to $6.5 \%$ under test (4). Data showed also that the lowest value for SEL was under test
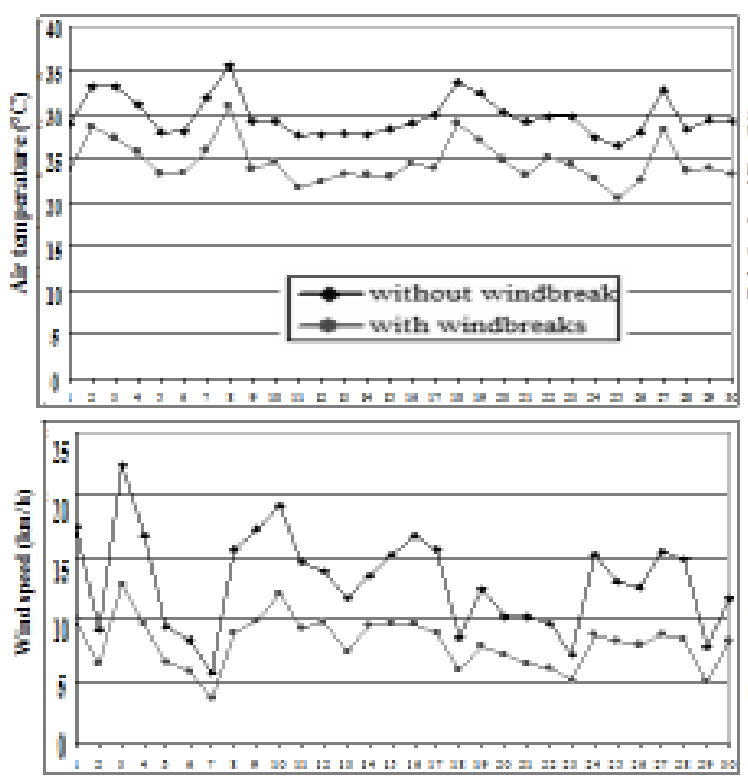

Days
(4) with treatment $\mathrm{T}_{4}(2.9 \%)$ and the highest value for SEL was under test (3) with treatment $\mathrm{T}_{2}(9.6 \%)$. On the other hand, SEL values at all treatments $\left(\mathrm{T}_{5}, \mathrm{~T}_{6}, \mathrm{~T}_{7}\right.$ and $\left.\mathrm{T}_{8}\right)$ with the absence of windbreaks increased and became ranged from $12.2 \%$ to $17.1 \%$ under test (5). While ranged from $17.8 \%$ to $26.8 \%$ under test (6), ranged from $19.2 \%$ to $28.7 \%$ under test (7) and ranged from $10 \%$ to $12.7 \%$ under test (8). Data showed also that the lowest value for SEL was under test (8) with treatment $\mathrm{T}_{5}(10 \%)$ and the highest value for SEL was under test (7) with treatment $T_{6}$ $(28.7 \%)$, when wind speed increased, as a result of windbreaks being absence, there was increasing in SEL. This SEL represents the extra water to be pumped from the source.
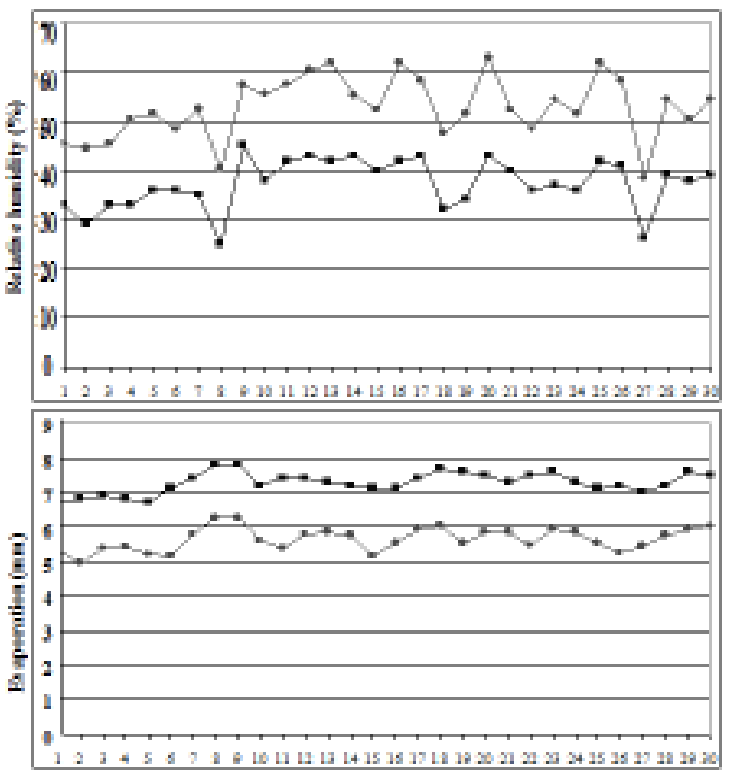

Days

Figure 2. Effect of the presence and absence windbreaks on climatic variables and evaporation during June.
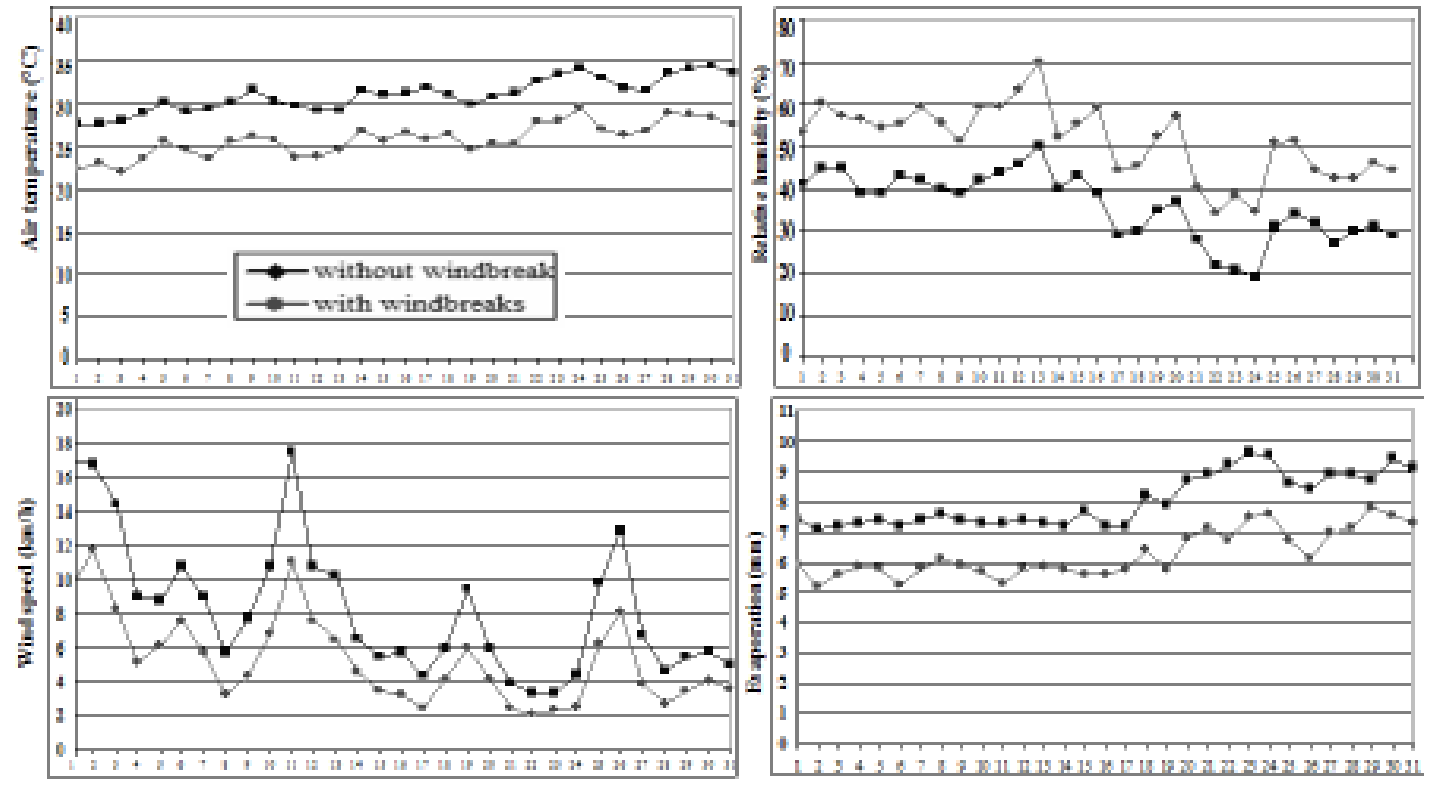

Days

Days

Figure 3. Effect of the presence and absence windbreaks on climatic variables and evaporation during July. 

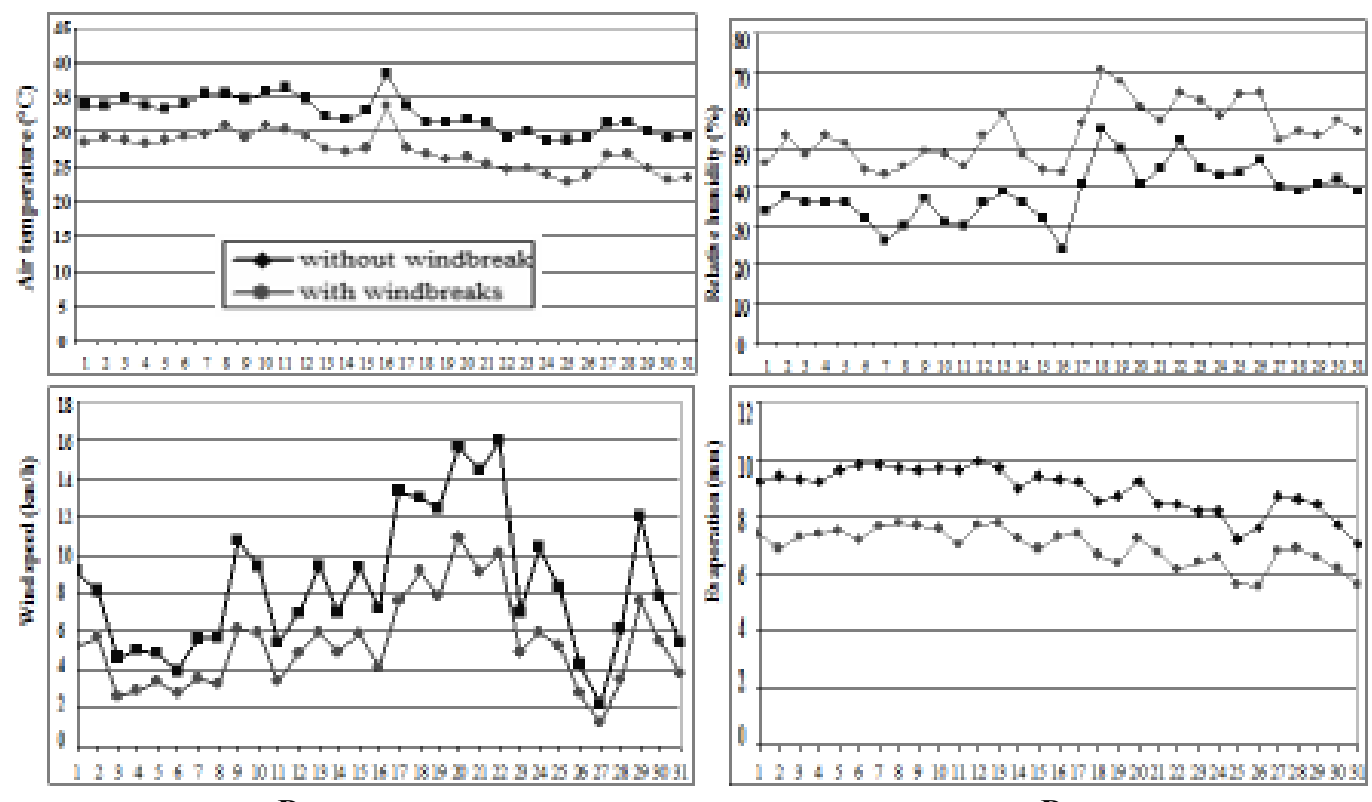

Days

Days

Figure 4. Effect of the presence and absence windbreaks on climatic variables and evaporation during August.
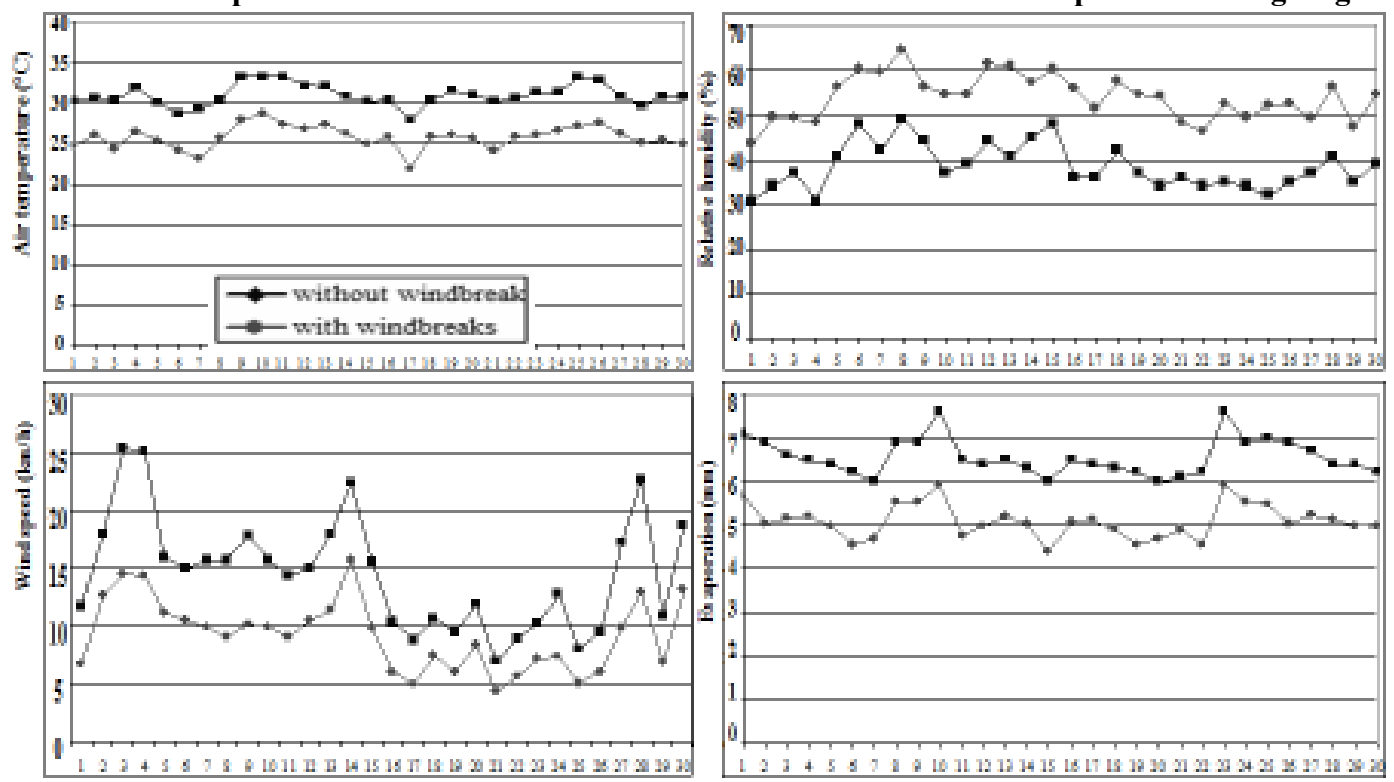

Days

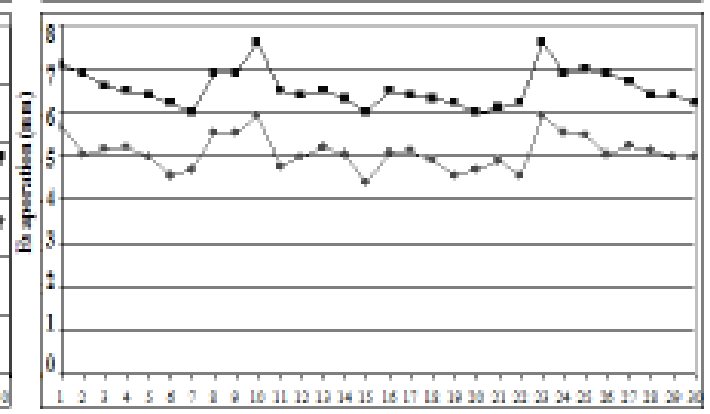

Days

Figure 5. Effect of the presence and absence windbreaks on climatic variables and evaporation during September.

Table 6. Spray evaporation loss $(\%)$ in the presence and absence of windbreaks.

\begin{tabular}{|c|c|c|c|c|c|c|c|c|c|}
\hline \multicolumn{4}{|c|}{ With windbreaks. } & \multicolumn{6}{|c|}{ Without windbreaks } \\
\hline & Test & $\begin{array}{l}\text { Test } \\
\text { (2) }\end{array}$ & $\begin{array}{c}\text { Test } \\
\text { (3) }\end{array}$ & $\begin{array}{l}\text { Test } \\
\text { (4) }\end{array}$ & & $\begin{array}{l}\text { Test } \\
\text { (5) }\end{array}$ & $\begin{array}{c}\text { Test } \\
\text { (6) }\end{array}$ & $\begin{array}{c}\text { Test } \\
\text { (7) }\end{array}$ & \\
\hline & & & & & & & & & 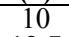 \\
\hline & & 8 & & & & & & & \\
\hline & & & & & & & & & \\
\hline & & 6.3 & 7.4 & 2.9 & & 6.7 & 23. & 26 & 12. \\
\hline
\end{tabular}

On the other hand, the effect of distance from sprinkler on spray evaporation loss (SEL) inside the irrigated area was determined. Data showed that spray evaporation loss in individual catch cans inside the irrigated area increased by the increasing in distance from the sprinkler. To show the variation of evaporation losses with distance, selected data for different climatic variables are given in Figures 6 and 7. At very high wind speeds, air temperature and low relative humidity the data showed that spray evaporation loss increase in the direction of the wind. Actual application rate $\left(\mathrm{m}^{3} / \mathrm{h}\right)$

Data in table 7 showed that, with presence of windbreaks, the higher actual application rate was obtained in treatment $\left(\mathrm{T}_{4}\right)$ while the lower actual application rate was obtained in treatment $\left(\mathrm{T}_{2}\right)$. On the other hand, with absence of windbreaks, the higher actual application rate was obtained in treatment $\left(\mathrm{T}_{5}\right)$ while the lower actual application rate was obtained in treatment $\left(\mathrm{T}_{6}\right)$.

Data in table 7 showed also that the higher actual application rate was obtained in Sep. (Test 4 and Test 8) which was 8.09 and $7.50 \mathrm{~m}^{3} / \mathrm{h}$ in treatments $\mathrm{T}_{4}$ and $\mathrm{T}_{5}$ respectively. While the lower actual application rate was obtained in August (Test 3 and Test 7) which were 7.53 and $5.94 \mathrm{~m}^{3} / \mathrm{h}$ in treatments $\mathrm{T}_{2}$ and $\mathrm{T}_{6}$ respectively. 
In generally, with the presence of windbreaks, the actual application rate in treatments $\left(\mathrm{T}_{1}, \mathrm{~T}_{2}, \mathrm{~T}_{3}\right.$ and $\left.\mathrm{T}_{4}\right)$ was higher than with the absence of windbreaks, in treatments $\left(\mathrm{T}_{5}, \mathrm{~T}_{6}, \mathrm{~T}_{7}\right.$ and $\left.\mathrm{T}_{8}\right)$.

Table 7. Actual application rate $\left(\mathrm{m}^{3} / \mathrm{h}\right)$ of sprinkler in the presence and absence of windbreaks.

\begin{tabular}{|c|c|c|c|c|c|c|c|c|c|}
\hline \multicolumn{5}{|c|}{ With windbreaks. } & \multicolumn{5}{|c|}{ Without windbreaks } \\
\hline reat & $\begin{array}{l}\text { Test } \\
\text { (1) }\end{array}$ & $\begin{array}{c}\text { Test } \\
\text { (2) }\end{array}$ & $\begin{array}{c}\text { Test } \\
\text { (3) }\end{array}$ & $\begin{array}{l}\text { Test } \\
\text { (4) }\end{array}$ & & $\begin{array}{c}\text { Test } \\
\text { (5) }\end{array}$ & $\begin{array}{c}\text { Test } \\
\text { (6) }\end{array}$ & $\begin{array}{c}\text { Test } \\
\text { (7) }\end{array}$ & $\begin{array}{c}\text { Test } \\
\text { (8) }\end{array}$ \\
\hline$\overline{\mathrm{T}_{1}}$ & 7.81 & 7.72 & 7.61 & 7.93 & $\mathrm{~T}_{5}$ & 7.31 & 6.85 & 6.73 & 7.50 \\
\hline $\mathrm{T}_{2}$ & 7.71 & 7.59 & 7.53 & 7.79 & $\mathrm{~T}_{6}$ & 6.91 & 6.10 & 5.94 & 7.27 \\
\hline $\mathrm{T}_{3}$ & 7.90 & 7.75 & 7.63 & 8.01 & $\mathrm{~T}_{7}$ & 7.00 & 6.47 & 6.33 & 7.31 \\
\hline $\mathrm{T}_{4}$ & 7.95 & 7.81 & 7.71 & 8.09 & $\mathrm{~T}_{8}$ & 6.94 & 6.38 & 6.13 & 7.29 \\
\hline
\end{tabular}

\section{Coefficient uniformity (\%)}

Data in table 8 showed that, with presence of windbreaks, the higher coefficient uniformity was obtained in treatment $\left(\mathrm{T}_{4}\right)$ while the lower coefficient uniformity was obtained in treatment $\left(\mathrm{T}_{2}\right)$. On the other hand, with absence of windbreaks, the higher coefficient uniformity was obtained in treatment $\left(T_{5}\right)$ while the lower coefficient uniformity was obtained in treatment $\left(\mathrm{T}_{6}\right)$. Data showed also that the higher coefficient uniformity was obtained in June (Test 1 and Test 5) which was $96.1 \%$ and $77.8 \%$ in treatments $\mathrm{T}_{4}$ and $\mathrm{T}_{7}$ respectively. While the lower coefficient uniformity was obtained in August (Test 3 and Test 7) which were $80 \%$ and $62.5 \%$ in treatments $\mathrm{T}_{2}$ and $\mathrm{T}_{6}$ respectively.

In generally, with the presence of windbreaks, coefficient uniformity in treatments $\left(T_{1}, T_{2}, T_{3}\right.$ and $\left.T_{4}\right)$ was higher than with the absence of windbreaks, in treatments $\left(\mathrm{T}_{5}, \mathrm{~T}_{6}, \mathrm{~T}_{7}\right.$ and $\left.\mathrm{T}_{8}\right)$.

Table 8. Coefficient uniformity $(\%)$ in the presence and absence of windbreaks.

\begin{tabular}{|c|c|c|c|c|c|c|c|c|c|}
\hline \multicolumn{5}{|c|}{ With windbreaks. } & \multicolumn{5}{|c|}{ Without windbreaks } \\
\hline & $\begin{array}{c}\text { Test } \\
\text { (1) }\end{array}$ & $\begin{array}{c}\text { Test } \\
\text { (2) }\end{array}$ & $\begin{array}{c}\text { Test } \\
\text { (3) }\end{array}$ & $\begin{array}{c}\text { Test } \\
\text { (4) }\end{array}$ & & $\begin{array}{c}\text { Test } \\
\text { (5) }\end{array}$ & $\begin{array}{c}\text { Test } \\
\text { (6) }\end{array}$ & $\begin{array}{c}\text { Test } \\
\text { (7) }\end{array}$ & $\begin{array}{c}\text { Test } \\
\text { (8) }\end{array}$ \\
\hline & 90.1 & 8 & 83 & 87.2 & & 7 & 7 & 7 & 74 \\
\hline & 87 & 82.2 & & 83.1 & $\mathrm{~T}_{6}$ & & & & 66 \\
\hline & 93 & 88 & .7 & 90 & & & & 0 & 72.2 \\
\hline & 96.1 & 90 & 87.5 & 92.3 & 1 & 73 & 72 & 68 & 70 \\
\hline
\end{tabular}
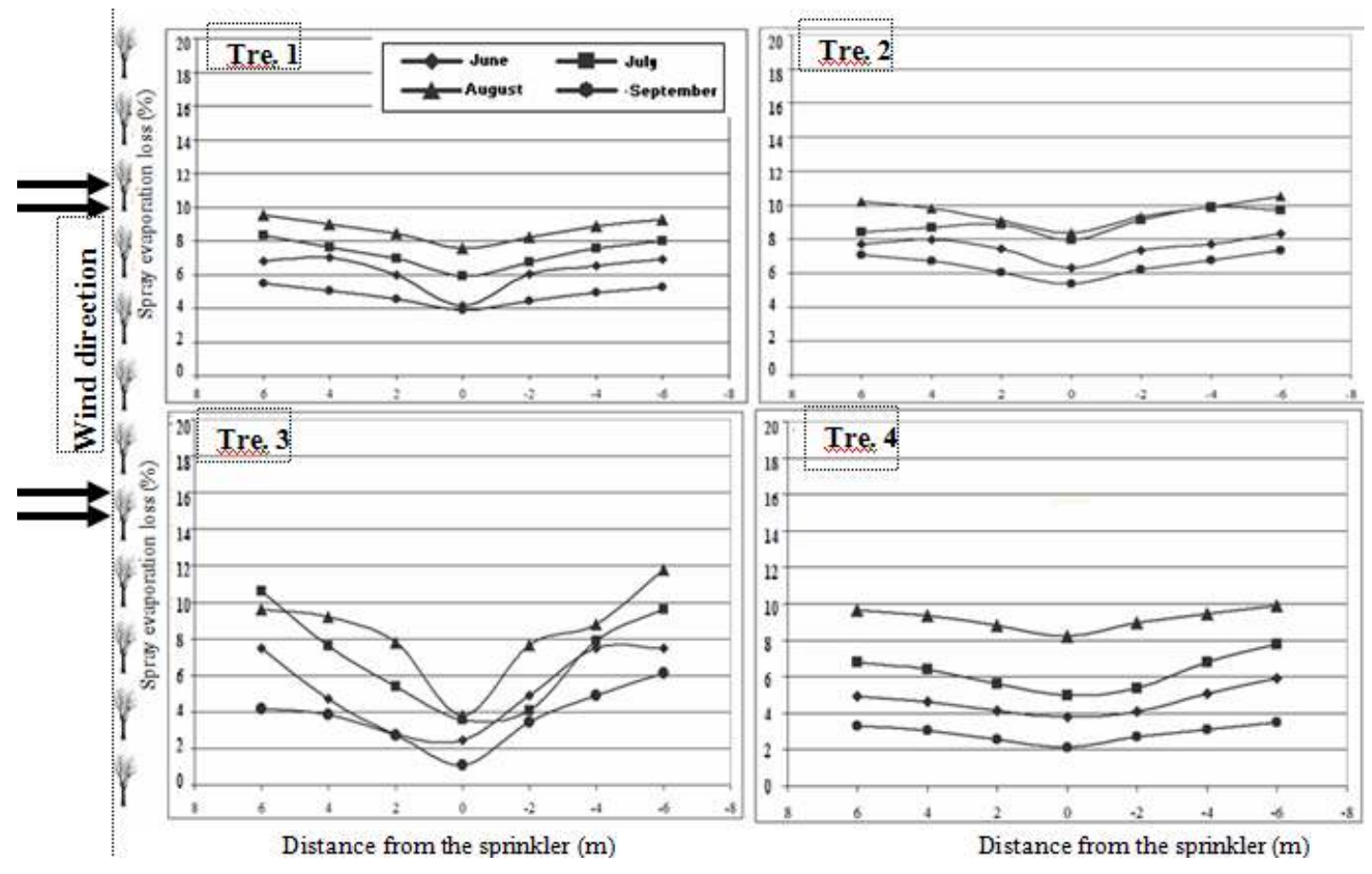

Figure. 6. Spray evaporation loss with the presence of windbreaks.

\section{Distribution uniformity (\%)}

Data in table 9 showed that, with presence of windbreaks, the higher distribution uniformity was obtained in treatment (T4) while the lower distribution uniformity was obtained in treatment (T2). On the other hand, with absence of windbreaks, the higher distribution uniformity was obtained in treatment (T5) while the lower distribution uniformity was obtained in treatment (T6). Data showed also that the higher distribution uniformity was obtained in June (Test 1 and Test 5) which was $86.2 \%$ and $72.6 \%$ in treatments $\mathrm{T} 4$ and $\mathrm{T} 5$ respectively. While the lower distribution uniformity was obtained in August (Test 3 and Test 7) which were 68.5\% and $45.3 \%$ in treatments $T_{2}$ and $T_{6}$ respectively.
In generally, with the presence of windbreaks, distribution uniformity in treatments $\left(T_{1}, T_{2}, T_{3}\right.$ and $\left.T_{4}\right)$ was higher than with the absence of windbreaks, in treatments $\left(\mathrm{T}_{5}, \mathrm{~T}_{6}, \mathrm{~T}_{7}\right.$ and $\left.\mathrm{T}_{8}\right)$.

Table 9. Distribution uniformity $(\%)$ in the presence and absence of windbreaks.

\begin{tabular}{|c|c|c|c|c|c|c|c|c|c|}
\hline \multicolumn{5}{|c|}{ With windbreaks. } & \multicolumn{5}{|c|}{ Without windbreaks } \\
\hline & $\begin{array}{c}\text { Test } \\
\text { (1) }\end{array}$ & $\begin{array}{c}\text { Test } \\
\text { (2) }\end{array}$ & Test & & & Test & Test & $\begin{array}{c}\text { Test } \\
\text { (7) }\end{array}$ & 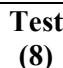 \\
\hline & 80.5 & 76. & 72.3 & 781 & & & & & \\
\hline & & & & & & & & & \\
\hline & & & & & & & & & \\
\hline & 86.2 & 81.1 & 79.6 & 83.3 & $\pi$ & 03.4 & 61.2 & 54.3 & 57.3 \\
\hline
\end{tabular}




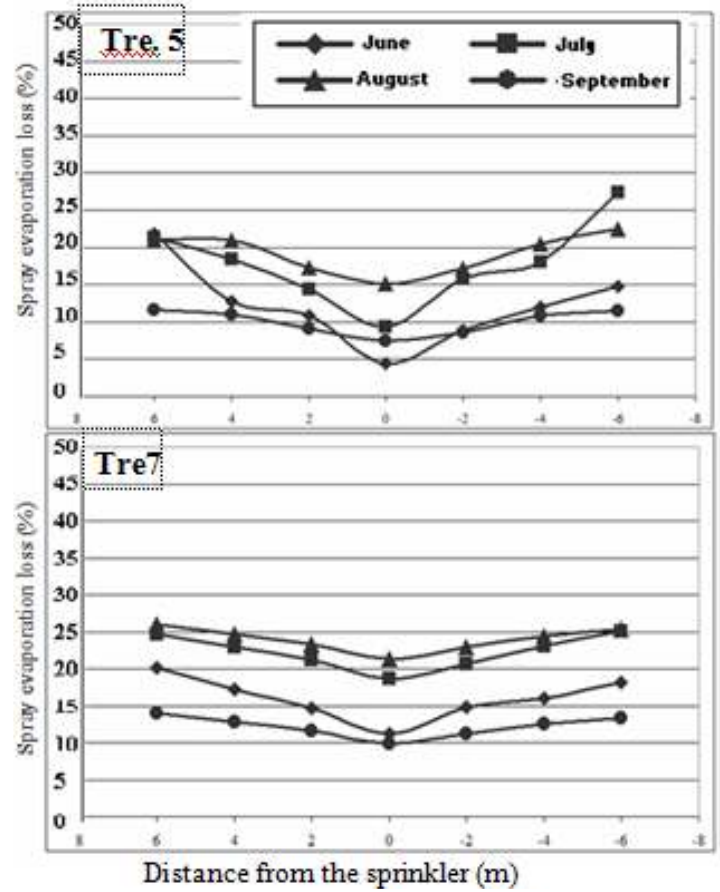

the sprinkler $(\mathrm{m})$
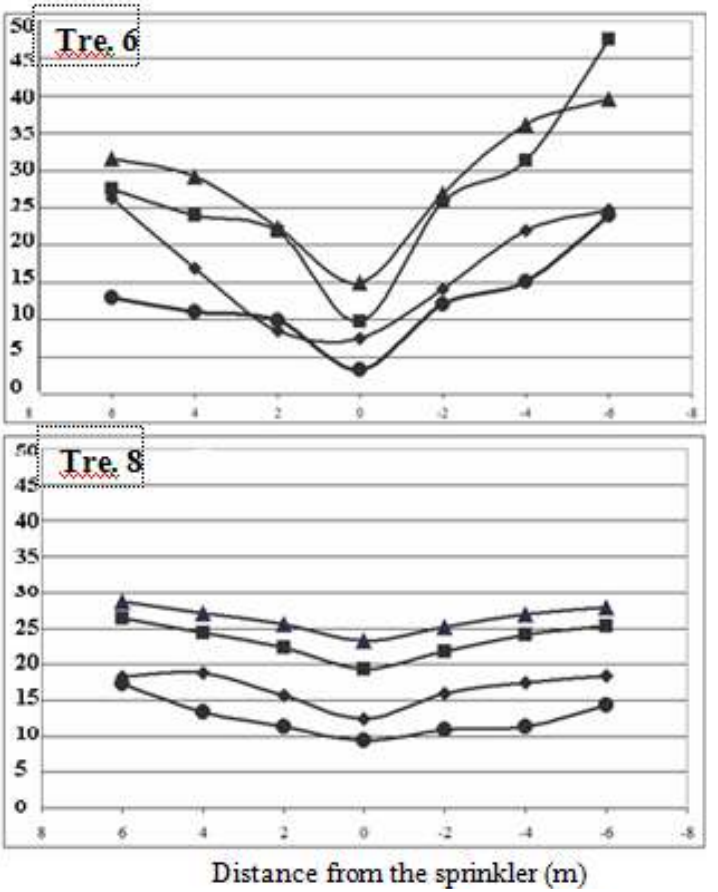

Distance from the sprinkler $(\mathrm{m})$
Yield (kg/fed)

The data in table (10) showed the effects of presence and absence of windbreaks, height of rotating sprinkler and layout (design) of sprinkler irrigation on Pods yield (kg/ fed.) of peanut. The Pods yield was significantly increased due to the presence of windbreaks and the low height of rotating sprinkler $(50 \mathrm{~cm})$ compared with Pods yield under absence of windbreaks and the increasing in the height of rotating sprinkler to $70 \mathrm{~cm}$. The presence of windbreaks increased Pods yield by $23.85 \%, 25.92 \%$, $28.62 \%$ and $30.41 \%$ more than the absence of windbreaks, with the same height of rotating sprinkler and the same layout. The higher Pods yield (1630.54 and 1575.83 $\mathrm{kg} / \mathrm{fed}$.) in this study was produced by interaction between presence of windbreaks and the low height of rotating sprinkler $(50 \mathrm{~cm})$. While, the lowest Pods yield (1043.5 and $1096.44 \mathrm{~kg} / \mathrm{fed}$.) in this study were produced due to interaction between the absence of windbreaks and the increasing height of rotating sprinkler to $70 \mathrm{~cm}$.

Table 10. Pods yield (kg/ fed.) of peanut under all treatments.

\begin{tabular}{lccc}
\hline $\begin{array}{l}\text { No. of } \\
\text { treatment }\end{array}$ & $\begin{array}{c}\text { Yield } \\
\text { (kg/fed) }\end{array}$ & $\begin{array}{c}\text { No. of } \\
\text { treatment }\end{array}$ & $\begin{array}{c}\text { Yield } \\
\text { (kg/fed) }\end{array}$ \\
\hline $\mathrm{T}_{1}$ & 1439.87 & $\mathrm{~T}_{5}$ & 1134.65 \\
$\mathrm{~T}_{2}$ & 1408.67 & $\mathrm{~T}_{6}$ & 1043.5 \\
$\mathrm{~T}_{3}$ & 1575.83 & $\mathrm{~T}_{7}$ & 1124.87 \\
$\mathrm{~T}_{4}$ & 1630.54 & $\mathrm{~T}_{8}$ & 1096.44 \\
\hline
\end{tabular}

\section{Irrigation water use efficiency $\left(\mathrm{kg} / \mathrm{m}^{3}\right)$}

The results in table (11) indicate the effect showed the effects of presence and absence of windbreaks, height of rotating sprinkler and layout (design) of sprinkler irrigation on irrigation water use efficiency based on pods yield. Irrigation water use efficiency was significantly decreased due to the absence of windbreaks and the low height of rotating sprinkler compared to the presence of windbreaks the increasing in height of rotating sprinkler. The highest
IWUE of peanut pods $\left(0.431\right.$ and $\left.0.416 \mathrm{~kg} / \mathrm{m}^{3}\right)$ in this study was resulted due to the interaction between presence of windbreaks and the low height of rotating sprinkler $(50 \mathrm{~cm})$. Meanwhile the lowest values $(0.276$ and $\left.0.290 \mathrm{~kg} / \mathrm{m}^{3}\right)$ were resulted due to the interaction between absence of windbreaks and the increasing in height of rotating sprinkler $(70 \mathrm{~cm})$.

Table 11. Water use efficiency $\left(\mathrm{kg} / \mathrm{m}^{3}\right)$ under all treatments.

\begin{tabular}{lccc}
\hline $\begin{array}{l}\text { No. of } \\
\text { treatment }\end{array}$ & $\begin{array}{c}\text { WUE } \\
\left(\mathbf{k g} / \mathbf{m}^{3}\right)\end{array}$ & $\begin{array}{c}\text { No. of } \\
\text { treatment }\end{array}$ & $\begin{array}{c}\text { WUE } \\
\left(\mathbf{k g} / \mathbf{~ m}^{\mathbf{3}}\right)\end{array}$ \\
\hline T1 & 0.380 & $\mathrm{~T} 5$ & 0.300 \\
T2 & 0.372 & $\mathrm{~T} 6$ & 0.276 \\
T3 & 0.416 & $\mathrm{~T} 7$ & 0.297 \\
T4 & 0.431 & $\mathrm{~T} 8$ & 0.290 \\
\hline
\end{tabular}

\section{CONCLUSION}

1-The relationship between different climatic variables (relative humidity, air temperature and wind speed) and spray evaporation loss (SEL) was evaluated to determine SEL related to varies in the climatic variables. This data is important because it provides knowledge of the most important variables if spray evaporation loss is to be lowered.

2-Absence of windbreaks was expected to cause decrease in relative humidity and increasing in the wind speed and air temperature in the field. Accordingly, the increasing in wind speed and air temperature led to an increase in spray evaporation loss, there was a corresponding increase in evapotranspiration. This spray evaporation loss lead to the extra water application to be pumped from the source.

3-Yield performances changed according to absence or presence the windbreak. With the presence of windbreak, peanut productions were higher than those obtained in the zone without the windbreaks by range 23 to $30 \%$. 
4-finally, with next climate variables projections showing that the Assuit region will get hotter, windbreaks can prevent water losses associated with sprinkler irrigation.

\section{REFERENCES}

Allen, G. R.; Pereira, L. S.; Raes, D. and Smith, M. (1998) Crop evapotranspiration, guidelines for competing crop water requirements. FAO. Irrigation and drainages paper (56). Rome, Italy.

Bavi, A., Kashkuli, H. A., Boroomand, S., Naseri, A., \& Albaji, M. (2009). Evaporation losses from sprinkler irrigation systems under various operating conditions. Journal of Applied Sciences, 9(3), 597600. doi: 10.3923/jas.2009.597.600

Christiansen, J. E. (1942). Irrigation by sprinkler. Univ. of California, Berkeley, BuI. 670. OCT.

de Vries, T. T., Cochrane, T. A., \& Galtier, A. (2010). Saving irrigation water by accounting for windbreaks. Paper presented at the Sustainable Irrigation Conference, Bucharest, Romania.

Dickey, G. L. (1988). Crop water use and water conservation benefits from windbreaks. Agriculture, Ecosystems and Environment, 22(23), 381-392. doi: 10.1016/0167-8809(88)90033-3

Doorenbos, J. and Pruitt (1977) Crop water requirement. FAO. Irrigation and drainage paper 24, Rome, Italy.

Eric K. K. (2015). The effect of windbreaks on the effectiveness of sprinkler irrigation systems. University of Canterbury. Water ways Centre for Freshwater Management. Christchurch, New Zealand. A thesis submitted in partial fulfilment of the requirements for the Degree in Master of Water Resource Management.

FAO (1979) Yield response to water. Irrigation and drainage paper 33, Rome, Italy.

Guan, D., Zhang, Y., \& Zhu, T. (2003). A wind-tunnel study of windbreak drag. Agricultural and Forest Meteorology, 118(1), 75-84. doi: 10.1016/S01681923(03)00069-8
Jackson, M. L. (1973) Soil chemical analysis. PrenticeHall, Inc. Englewood Cliffs, N.J. New Delhi, India.

James, L. G. (1988) Principles of farm irrigation systems design. Washington State University.: 543.

Keller, J. and Bliesner, R. D. (1990) Sprinkler and trickle irrigation. Chapt. 6, (set sprinkler uniformity and efficiency. And Chapt. 20 Emitter selection and design criteria).

Kincaid, D. C., \& Longley, T., S. (1989). A water droplet evaporation and temperature model. Transactions of the American Society of Agricultural \& Biological Engineers, 32(2), 457- 463.

Klute, A. (1986) Method of soil analysis. Part -1. physical and Mineralogical methods.2nd American Society of Agronomy, Madison, Wisconsin, USA.

Playán, E., Salvador, R., Faci, J. M., Zapata, N., MartínezCob, A., \& Sánchez, I. (2005). Day and night wind drift and evaporation losses in sprinkler solid-sets and moving laterals. Agricultural Water Management, 76(3), 139-159. doi: 10.1016/ j.agwat.2005.01.015

Smajstrla, A. G., \& Zazueta, F. S. (2003). Evaporation loss during sprinkler irrigation. In I. o. F. a. A. S. Agricultural and Biological Engineering Department, University of Florida, USA. (Ed.).

Uddin, J., Smith, R., Nigel, H., \& Foley, J. (2010). Droplet evaporation losses during sprinkler irrigation: An overview. Paper presented at the One Water Many Future, Australian Irrigation Conference and Exhibition, Sydney, 8-10 June 2010.

Vites, F. G. (1965) Increasing water use efficiency by soil management. America Society Agronomy, Madison, Wisconsin, p. 259-274.

Zazueta, F. S. (2011). Evaporation loss during sprinkler irrigation. BUL290. Revised November 2011. Gainsville, Florida: IFAS Extension, University of Florida.

\footnotetext{
تأثير مصدات الرياح وبعض العوامل التصميمية على أداء نظام الري بالرش.

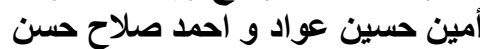
معهد بحوث الهندسة الزراعية ـ مركز البحوث احمل هين الزراعية - وزارة الزراعة

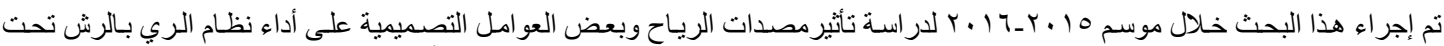

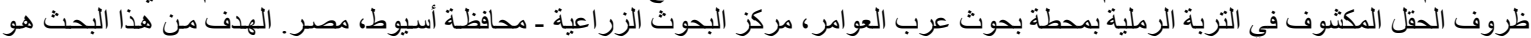

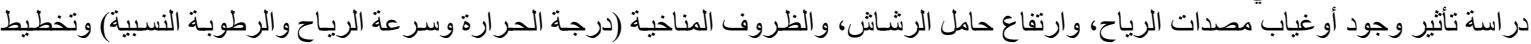

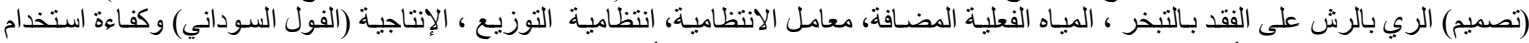

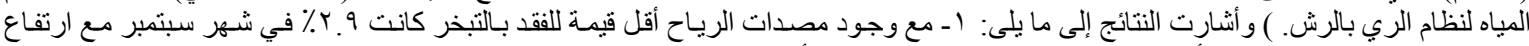

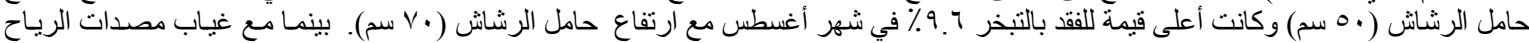

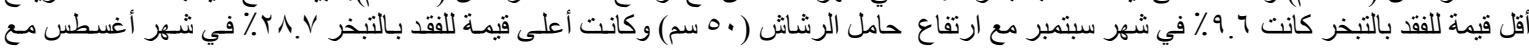

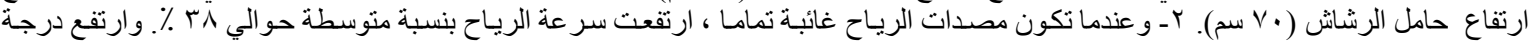

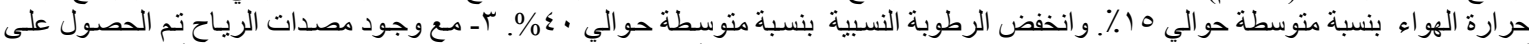

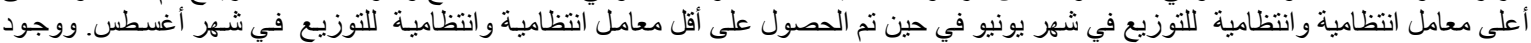

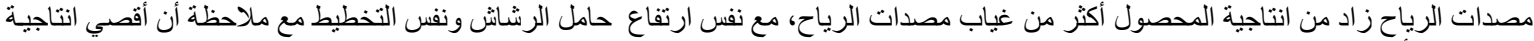

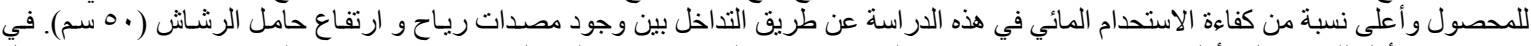

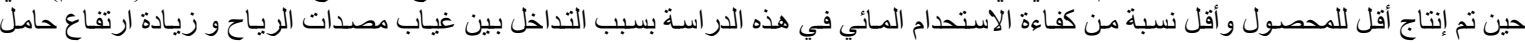

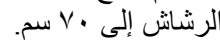

